\title{
Potential of Chlorella Species as Feedstock for Bioenergy Production: A Review
}

\author{
Baiba IEVINA ${ }^{1 *}$, Francesco ROMAGNOLI $^{2}$ \\ ${ }^{1,2}$ Institute of Energy systems and environment, Riga Technical University, Äzenes 12-k1, Riga, Latvia
}

\begin{abstract}
Selection of appropriate microalgae strain for cultivation is essential for overall success of large-scale biomass production under particular environmental and climate conditions. In addition to fast growth rate and biomass productivity, the species ability to grow in wastewater must also be considered to increase the economic feasibility of microalgae for bioenergy purposes. Furthermore, the content of bioactive compounds in a strain must be taken into account to further increase the viability by integration of biorefinery concept. Chlorella spp. are among the most studied microalgal species. The present review attempts to unfold the potential of species of the genus Chlorella for bioenergy production integrating applicability for wastewater treatment and production of high added-value compounds. Several key features potentially make Chlorella spp. highly beneficial for bioenergy production. Fast growth rate, low nutritional requirements, low sensitivity to contamination, adaptation to fluctuating environments, ability to grow in photoautotrophic, heterotrophic and mixotrophic conditions make Chlorella spp. highly useful for outdoor cultivation coupled with wastewater treatment. Chlorella is a source of multiple bioactive compounds. Most promising high-value products are chlorophylls, lutein, $\beta$-carotene and lipids. Here we demonstrate that although many Chlorella spp. show similar characteristics, some substantial differences in growth and response to environmental factors exist.
\end{abstract}

Keywords - Biomass; biorefinery; microalgae; wastewater treatment

\section{INTRODUCTION}

Microalgae are regarded as a promising sustainable energy source due to their fast growth rate, high productivity and ability to accumulate large quantities of lipids [1]. Microalgae biomass has vast applicability, it can be converted to various types of renewable bioenergy, e.g. biogas, biodiesel, biomethane, biohydrogen, bioethanol. Moreover, microalgae biomass and high added-value compounds extracted from the biomass can be used in food industry, medicine, textile industry, feed, aquaculture, agriculture and cosmetology [2]. Several studies have been conducted on the potential and economic feasibility of large-scale microalgae cultivation for bioenergy production [3]-[5]. However, most studies have concluded that economic viability of bioenergy production from microalgae biomass is still an ambitious goal and vast improvements must be implemented before the stage of a commercial low-cost microalgae biomass production. Currently large-scale biomass production is not viable mainly due to high production costs and low productivity of microalgae strains. Lately studies have been focusing on possible solutions to decrease production costs at the same time increasing the efficiency of biomass yield. Optimisation of cultivation conditions must be attained to increase the productivity of microalgae

* Corresponding author.

E-mail address: Baiba.Ievina@rtu.lv

C2020 Baiba Ievina, Francesco Romagnoli.

This is an open access article licensed under the Creative Commons Attribution License (http://creativecommons.org/

licenses/by/4.0), in the manner agreed with Sciendo. 
mass cultures. Furthermore, effective and low-cost cultivation technology is essential to increase overall biomass productivity. Open ponds and various types of closed photobioreactors have been utilized for microalgae cultivation with certain advantages and disadvantages. Although no consensus has been reached on the most suitable type of cultivation vessel for large-scale cultures, some researchers have proposed that open pond cultivation is more commercially viable for bioenergy production [2], [3], [6], [7].

Lately several novel strategies have been proposed to increase the efficiency and eliminate the costs of microalgae cultivation. Use of wastewater as a nutrient source for microalgae growth and biorefinery are two of the most promising strategies suggested [8], [9]. Many studies have been conducted recently to test microalgae growth in various wastewaters in search for low-cost nutrients. Microalgae cultivation in wastewater offers the possibility of low-cost biomass production at the same time treating wastewater. Furthermore, integrated extraction of high addedvalue co-products from microalgae biomass is a more sustainable and economical approach to microalgae biomass utilization. Additionally, integration of a cultivation system close to the combustion power plant can benefit from the use of flue gas as a source of $\mathrm{CO}_{2}$ for increased microalgae growth.

Selection of an appropriate microalgae strain is a crucial factor for high productivity under the selected environment and for the overall success of large-scale biomass production. There are over 70000 species of microalgae, many of them have not been characterized [10]. Moreover, only a very small fraction of all species has been used in studies of biomass and bioenergy production. The ideal strain for large-scale outdoor biomass production must have the following characteristics: fast growth rate, wide temperature tolerance, high competitiveness, limited nutrient requirements, high $\mathrm{CO}_{2}$ uptake, tolerance to shear force and to various contaminants in flue gas (e.g. $\mathrm{NO}_{\mathrm{x}}, \mathrm{SO}_{\mathrm{x}}$ ) and wastewater (e.g. heavy metals, ammonium), adaptation ability to fluctuating environmental conditions (light, $\mathrm{pH}$, etc.) and source high-value co-products [1], [11]. Extensive research has been carried out focusing on selection of microalgal strains that can be cultivated for large-scale biomass yield. Among microalgal strains, various Chlorella species have been studied extensively. Green microalga Chlorella vulgaris has received much attention and is probably the most studied microalga.

This review attempts to investigate the potential of Chlorella species for large-scale microalgae cultivation for bioenergy production, with an emphasis on investigation of the capacity for biorefinery and the use of wastewater streams for cultivation of potential species to increase the economic feasibility of microalgal biofuels.

\section{Characterization of Genus Chlorella}

\subsection{General description of Chlorella}

Chlorella is a genus of small, single-celled green algae belonging to the division Chlorophyta. Chlorella cells are non-motile without flagella in a size of 2 to $10 \mu \mathrm{m}$ in diameter [12]. Chlorella spp. have been widely studied since early 1950ies when the first large-scale cultivation was set up in USA for biodiesel production; however, commercial cultivation started in 1961. in Japan, where Chlorella was grown as a source of protein for food and feed [13]. Chlorella spp. are microalgae with high commercial importance [14] and C. vulgaris is one of a few microalgae cultivated commercially for food and feed [13]. Chlorella is a cosmopolitan genus with its species found in diverse water habitats including freshwater, marine and wastewater [13], [15]. Species can grow well in a wide temperature range that makes them particularly useful for various applications in outdoor conditions. 
Research shows that Chlorella spp. can withstand temperatures from $5^{\circ} \mathrm{C}$ to $42^{\circ} \mathrm{C}$ [16], [17]. Key characteristics of selected Chlorella spp. are shown in Table A1 in the Annex.

Although Chlorella has low nutritional requirements [13], the species can withstand high nutrient concentration [18] that may be advantageous for cultivation in high strength wastewater thereby increasing its competitiveness over other species of microorganisms particularly in outdoor cultivation. Other characteristics such as fast growth rate, low sensitivity to contamination and unfavourable environments [19] also make Chlorella favourable for wastewater treatment and cultivation in open ponds under fluctuating environmental conditions.

Genus Chlorella has a simple life cycle. Reproduction is exclusively asexual by cell division, most often producing four to eight daughter cells [20]. Cells have thick resistant walls with glucosamine as a main wall component [20], [21]. It has its advantages and disadvantages. Robust, non-flagellated cells make Chlorella shear resistant beneficial for cultivation in bioreactors where cells are less likely to be damaged by mixing. In contrast, large flagellated cells like those of Dunaliella spp. are shear sensitive and are more prone to damage during mixing and pumping in bioreactors [18]. However, looking from a biorefinery point of view, the hard resistant cell walls of Chlorella are a major drawback as they require pre-treatment for efficient extraction of bio-compounds increasing the extraction time and costs.

\subsection{Taxonomy}

Classification of Chlorella is not straightforward and species cannot be identified based on morphological features alone [13]. More than 100 microalgae from various habitats have been historically assigned to genus Chlorella [22]. Classification of Chlorella remains a challenge even today. Although, the genus Chlorella has undergone extensive changes in recent years, reorganization of the genus is not complete, several new suggestions for rearrangements of the genus have been proposed [14], [20], [23]. More powerful methods than morphological features are required for the identification of species. Novel, more sensitive identification techniques, such as molecular phylogeny and bioinformatics have been introduced making classification more reliable. Use of molecular markers has revealed that many species formerly assigned to Chlorella in fact belong to different lineages of green microalgae [24]. Based on biochemical, physiological, ultrastructural characters and molecular tools, Huss suggested only four species to be kept in the genus Chlorella, namely, C. vulgaris, $C$. lobophora, C. sorokiniana and C. kessleri [20]. However, another research on taxonomy of Chlorella suggests that five "true" Chlorella species exist, namely C. vulgaris, C. lobophora, C. sorokiniana, C. heiozoae and C. variabilis [23]. Chlorella kessleri has been reclassified as Parachlorella kessleri [22]. Most strains formerly identified as C. pyrenoidosa have been reclassified as other strains of the genus Chlorella and other taxa [14]. In the study of Kessler and Huss, several strains of $C$. pyrenoidosa from UTEX collection have been tested with biochemical and physiological markers and it was found that most of the strains belong to different strains of Chlorella such as $C$. vulgaris, C. sorokiniana and $C$. fusca var. vacuolate [25]. C. pyrenoidosa is no longer a valid species and most of the strains formerly assigned as $C$. pyrenoidosa have now been reclassified. Champenois suggested that Coelastrella vacuolate is the current valid name for this C. pyrenoidosa [14]. Just a few studies are available on C. lobophora [26], [27], therefore, more research is required to assess the potential of $C$. lobophora for bioenergy production. 
In the current review we focus on the most frequently studied Chlorella species, although some species have been suggested for reclassification into different genus such as Parachlorella and Auxenochlorella.

\subsection{High-Value Products}

Lately, microalgal biorefinery is receiving increasing interest. A commercial potential of microalgae biomass is still an untapped resource. Microalgae are a source of bioproducts such as pigments, proteins, lipids, carbohydrates, vitamins and antioxidants with high commercial value. The extraction of these co-products is essential to improving the economic feasibility of microalgal bioenergy. Microalgae biorefinery concept is a new approach for better utilization of biomass potential, achieve higher viability and sustainability of bioenergy and move towards "zero waste" production in a circular economy framework. Biorefinery results in a cost-effective simultaneous production of bioenergy and various valuable bioproducts. Moreover, besides economic benefit biorefinery also minimizes the environmental impact with the more efficient use of resources and reduction of greenhouse gas emissions.

Studies indicate that Chlorella biomass has a wide range of potential applications in pharmaceutical, nutraceutical, agricultural and cosmetics industries [28], [29]. Chlorella is a source of many high value compounds nevertheless; it has most often been exploited as a protein source. Depending on the culture conditions, C. vulgaris contains up to $58 \%$ proteins and $C$. pyrenoidosa $57 \%$ that are between the highest rates of green microalgae [30]. Due to its high protein content $C$. vulgaris is used in health food industry and aquaculture [31]. It has been reported that $C$. vulgaris contains $37 \%$ starch [32] that can be useful for bio-ethanol production. Sulphur deficiency has been shown to increase starch content in cells that is followed by lipid accumulation in Chlorella species [33]. Many high value products are secondary metabolites that are biochemical compounds involved in adaptation of microalgae to changing environmental conditions. Examples of secondary metabolites are carotenoids, phycobiliproteins, phenolic compounds, alkaloids and lignin [34]. Synthesis of some secondary metabolites increases under stress conditions such as oxidative, osmotic or nutrient stress. Therefore, stress conditions must be induced to increase the production of these biochemicals.

Chlorella is a source of high value pigments such as lutein, astaxanthin and $\beta$-carotene; vitamins, especially vitamin B complex, ascorbic acid, $\alpha$-tocopherol and several other bioactive compounds [28]. Othman tested 6 green freshwater microalgae and found that C. vulgaris had the highest total carotenoid and $\beta$-carotene content, $81 \mu \mathrm{g} / \mathrm{g} \mathrm{DW}$ and $18 \mu \mathrm{g} / \mathrm{g}$ DW, respectively [35]. Moreover, highest lutein content (69 $\mu \mathrm{g} / \mathrm{g} \mathrm{DW})$ was found in Chlorella fusca. Although lutein traditionally is extracted from marigold flowers, the production of lutein is hampered by seasonal availability of marigold flowers. Microalgae can contain a considerable amount of lutein [36]-[38] and can be harvested all year round. Chlorella has shown good potential as a lutein source. However, lutein content is dependent on cultivation conditions, therefore, lutein extraction rate reported is highly variable. D'Este was able to extract $0.69 \mathrm{mg} / \mathrm{g}$ DW lutein from C. vulgaris [37]. Wei achieved $1.98 \mathrm{mg} / \mathrm{g} \mathrm{DW}$ lutein content in C.protothecoides [39], but Chen reached $5.88 \mathrm{mg} / \mathrm{g}$ DW lutein with two-stage heterotrophic culture of C. sorokiniana [38]. Lutein content in C. minutissima reached $8.24 \mathrm{mg} / \mathrm{g}$ DW in Dineshkumar's study [40], but the highest extraction reported was $10.4 \pm 5.5 \mathrm{mg} / \mathrm{g}$ DW in C. vulgaris in McClure's study using photoautotrophic cultivation mode [41]. In contrast, very low lutein was reported in Othman's study. $C$. vulgaris was found to produce $63 \mu \mathrm{g} / \mathrm{g}$ DW lutein but C. fusca $69 \mu \mathrm{g} / \mathrm{g}$ [35]. Although sustainable and economically viable lutein production still needs extensive research, lutein production rate of 
microalgae is reported to be 3 to 6 times higher than that of marigold flowers [42] and the results achieved so far are promising.

Recently, emphasis has been placed for the search of new bioactive compounds in microalgae with antibacterial, antifungal and anticancer activities. Chlorella spp. contain valuable bioactive peptides with antioxidant, anti-inflammatory and anticancer properties [43]. For example, C. pyrenoidosa contains polypeptide that exhibits antitumor activity [44]. This field is very promising, but requires more studies. Another example of bioactive compound with potentially high commercial interest is $\beta$-1,3-glucan - a polysaccharide best known for its immunostimulatory activity [28].

In agriculture Chlorella biomass has been applied as a bio-fertilizer and as a feedstock for animals. Algae biomass have been incorporated as a dietary supplement in farm animal, fish and poultry feed. For example, the addition of Chlorella biomass to poultry feed has showed improved growth, immune response and gut microflora [28].

\subsection{Wastewater Treatment}

Large-scale microalgae cultivation requires considerable amount of water and nutrients that makes up a large part of the cultivation costs. On the other hand, large volumes of wastewater in food and processing industries are generated containing valuable micro- and macro elements that can be used for microalgae cultivation. The use of wastewater as a low-cost nutrient source is one of the strategies proposed to reduce biomass production costs and increase the feasibility of low-cost bioenergy [45]. Wastewaters are complex mixtures with a variable composition depending on their origin. Generally, wastewater streams contain organic, inorganic and man-made compounds [46]. Microalgae are known to remove nutrients and heavy metals from wastewaters to the level that meets the requirements for discharge.

Wastewater use has multiple advantages on microalgae cultivation: (1) it is a source of nutrients for microalgae growth, (2) it provides a sustainable water source, and (3) it is a source of organic carbon for heterotrophic and mixotrophic growth [47]. The main environmental issue of microalgae cultivation - the need for enormous amounts of freshwater thus could be mitigated, moreover, it reduces expenses of nutrients required for microalgae cultivation.

Simultaneous nutrient removal and biomass production requires microalgae species to survive in specific conditions and reach high biomass yield. Species for wastewater treatment must exhibit good pollutant removal capacity mainly ammonium, nitrogen, phosphorus and heavy metals under specific environmental conditions. Due to large quantities of organic carbon in wastewaters, microalgae with heterotrophic metabolism are beneficial. It has been demonstrated that Chlorella spp. are capable to grow in autotrophic, heterotrophic and mixotrophic conditions [48]. In contrast to photoautotrophy that use solar energy and carbon dioxide, in heterotrophic metabolism microorganisms can utilize organic compounds from the environment as a source both for energy and carbon [47]. Simultaneous use of carbon dioxide and organic carbon, known as mixotrophy, can more efficiently utilize the available light and organic nutrients form wastewater thus potentially enhancing microalgae growth. Recently many studies have been aiming at optimizing heterotrophic and mixotrophic cultivation to overcome the limitations of autotrophic growth such as light deficiency. Several studies have shown higher efficiency in nutrient removal and biomass production in mixotrophic and heterotrophic cultivation mode compared to photoautotrophic conditions [49]-[51]. When cultivated in wastewater Chlorella is able to switch from phototrophic to heterotrophic or mixotrophic growth. Glucose is found to be the preferred source of carbon for Chlorella species [52]. Mixotrophy with glucose has resulted in a higher growth rate than 
autotrophic or heterotrophic cultivation [50]. Some studies have shown that mixotrophic cultivation is the most efficient [51] while others demonstrated better growth in heterotrophic cultivation [49].

Species competitiveness is another important consideration for assessment of species suitability for cultivation in wastewater. Wastewater contains biological contaminants such as bacteria and protozoa, therefore robust and fast-growing microalgae that can outcompete other species are crucial for cultivation in wastewater. Wastewater treatment requires fast and efficient pollutant removal in a possibly shortest period of time therefore, in addition to fast growth rate the potential algal strain must also be tolerant to weather fluctuations and high nutrient concentrations. Chlorella spp. are natural inhabitants of wastewater ponds [15], [53] and can survive in various wastewater streams showing great potential to adapt to various environmental conditions [15], [54]-[56]. Oberholster demonstrated that a combination of C. vulgaris and C.protothecoides is effective in nutrient removal from wastewater stabilization ponds (75\% total phosphorus and $43 \%$ total nitrogen removal) and Chlorella spp. stayed dominant after inoculation of ponds, moreover other microalgae species coexisted with Chlorella spp. in treatment ponds [57].

Chlorella spp. are found to be between predominant strains in wastewater ponds. Exploring waste stabilization ponds Palmer found that the most abundant and frequent genera were Chlorella, Ankistrodesmus, Scenedesmus, Euglena, Chlamydomonas, Oscillatoria, Micractinium and Golenkinia [58]. Furthermore, Palmer published another study with the results of an extensive research covering 165 studies and reported that Chlorella is between the top eight pollutanttolerant genera [53]. Moreover, screening top 17 strains with the best performance in wastewaters collected locally from natural freshwater habitats and wastewater, Zhou found that $60 \%$ belongs to Chlorella spp. [15] demonstrating superiority of Chlorella over other microalgae strains and indicating its potential for wastewater treatment. Ayre studied microalgal consortium in anaerobic digestate of piggery effluent with high ammonia content and found that Chlorella was dominant species at all ammonium concentrations [59]. Moreover, the consortium was able to grow in 800 and $1600 \mathrm{mg} \mathrm{NH}{ }_{4}^{+}-\mathrm{N} \mathrm{L}^{-1}$ showing superior resistance to high ammonium concentrations than other microalgae species. Chlorella spp. have been used in numerous studies and have shown good nitrogen and phosphorus removal rates. Generally, Chlorella spp. can remove $23 \%-100 \%$ nitrogen while phosphorus removal efficiency is $20 \%-100 \%$ [45]. However, not all microalgae strains can grow in wastewater. Caporngo observed lower growth and nutrient removal level of Nannochloropsis ocultata compared to C. vulgaris and C. kessleri [55]. Alvarez-Diaz found that Neochloris oleoabundans did not grow in wastewater [60]. According to Caporngo freshwater microalgae are preferable to wastewater cultivation than marine algae [55]. However, Chinnasamy observed that also marine algal species exhibit good growth in some wastewater (e.g. carpet mill effluent) without salt addition [61].

\subsection{Biomass Yield and Lipid Production}

Chlorella spp. are among the fastest growing microalgae, often reported being superior to other species [1], [62]. However, because growth rate is highly dependent on cultivation system and growth conditions, reported values are very wide making comparison between studies difficult. Growth rates and biomass productivity of Chlorella spp. are summarized in Table A2 in the Annex. Li compared biomass productivity of various Chlorella species and observed the highest productivity for C. kessleri UTEX 398 (2.01 g TVSS/L), followed by C. protothecoides strains UTEX 25 and UTEX 256 [48]. The lowest productivity (0.38 g TVSS/L) was observed for Chlorella fusca var. vacuolata, the species that is no longer assigned to genus Chlorella and reclassified as Coelastrella vacuolate. In the same study two 
strains of C. sorokiniana (UTEX 1230 and UTEX 2805) exhibited biomass productivity of 0.70 and 0.76 , respectively.

Chlorella species are capable of accumulating significant amounts of lipids, generally under stress conditions; furthermore, several strains are producing a fatty acid profile suitable for biodiesel production [2], [63], [64]. Lipid content in Chlorella spp. under normal growth conditions is generally around $20 \%$, higher lipid content has been reported in $C$. minutissima (31\%) but lower in C. protothecoides (11\%) [65]. However, by adjusting the growth conditions lipid content can reach $>50 \%$ [2], [65]. Nitrogen limitation is an effective strategy to increase lipid content in all Chlorella strains [65]. Reported lipid concentration in $C$. vulgaris ranges from $5 \%$ to $58 \%$ (DW) and lipid productivity from 11 to $40 \mathrm{mg} \mathrm{L} \mathrm{d}^{-1}$ [34]. Such a wide range of values could be explained with various growth conditions used in different studies.

Illman compared the growth and lipid production of five strains of Chlorella, C. vulgaris, C. emersonii, C. protothecoides, $C$. sorokiniana and marine strain C. minutissima [65]. Under nitrogen deficiency conditions the growth rate decreased in all strains except $C$. minutissima which remained in the same level. Highest lipid content was achieved in C. emersonii (63\%), C. minutissima $(57 \%)$ and C. vulgaris $(40 \%)$. Microalgae C. vulgaris and C. emersonii are promising species because of high growth rates that stay relatively high also under $\mathrm{N}$ limitation condition coupled with good lipid productivity. C. minutissima showed no decrease in growth rate under $\mathrm{N}$ limitation conditions and high lipid content. C. emersonii and $C$. minutissima show high lipid content in optimal growth conditions, $29 \pm 2.5 \%$ and $31 \pm 3.2 \%$, respectively. Although, reported lipid productivity of Chlorella spp. is variable, high lipid content achieved in some studies are suggesting that high lipid concentration in Chlorella can be reached, however, optimization is required.

\section{Characterization of Chlorella Species}

\subsection{Chlorella vulgaris}

C. vulgaris is a type species of genus Chlorella and the most widely studied algae of the genus. C. vulgaris has spherical, non-motile single cells with a cell size from 2 to $10 \mu \mathrm{m}$ in diameter [2]. C. vulgaris is a freshwater species and is known as one of the fastest growing microalgae strains with a doubling time of $16 \mathrm{~h}$ in photoautotrophic conditions [65]. C. vulgaris has rigid cell wall mainly composed of a chitosan-like layer, cellulose, hemicellulose, proteins, lipids and minerals [66]. Cells have a single chloroplast. C. vulgaris can accumulate starch or lipids under unfavourable conditions stored in cytoplasm or chloroplast [2], [65]. Reproduction is asexual by autosporulation. Most commonly four daughter cells are formed. C. vulgaris has a remarkable ability to withstand a wide range of temperatures, especially low temperatures. It has been demonstrated that $C$. vulgaris can withstand $5{ }^{\circ} \mathrm{C}$ and still do slow but continuous growth [16]. However, cells are not resistant to high temperature, already at $30^{\circ} \mathrm{C}$ considerable decrease in cell viability has been observed [67]. Optimal temperature of the species is between $25^{\circ} \mathrm{C}$ and $28{ }^{\circ} \mathrm{C}$ [67], [68].

Although a more alkaline medium is generally thought to be optimal for $C$. vulgaris growth [69], other studies have found that neutral $\mathrm{pH}(\mathrm{pH} 7)$ leads to a higher growth rate [70]. While a vast number of studies on $C$. vulgaris have been performed, data reported can significantly vary. For instance, it has been reported that $C$. vulgaris contains $42 \%-58 \%$ total proteins, but lipid content under optimal growth conditions varies between $5 \%$ and $40 \%$ of dry weight (DW) [2]. The observed wide range of values reported most likely originates from various growth conditions 
applied in different studies. Lipid content under normal growth conditions of $C$. vulgaris is around $20 \%$ [65]; however, during stress conditions, normal biochemical composition of cells changes, and an increase in lipids and decrease in proteins is often observed. Application of stress such as nitrogen starvation, can increase lipid content up to $58 \%$ [2] and lipids are mainly in the form of triacylglycerols (TAG). For example, dos Santos observed total lipids 19.6\% DW and 27.7\% TAG under optimal growth conditions [66]. Lipid content increased to $25.4 \% \mathrm{DW}$ after nitrogen starvation was applied, moreover, TAG content increased to $41.3 \%$. Lower percentage of PUFAs was also observed under nitrogen starvation mode compared to optimal growth conditions being more suitable for biodiesel production [66].

C. vulgaris is a source of bioactive compounds with commercial value that could be used for a biorefinery approach. C. vulgaris is rich in proteins, carbohydrates, lipids, pigments, minerals and vitamins [2]. Therefore, it has vast applicability in various fields such as human food, animal feed, cosmetology and medicine. Cells contain significant amounts of chlorophyll. Their content in C. vulgaris cells can reach up to $1-2 \%$ DW [2]. Cells also contain significant amounts of carotenoids, such as $\beta$-carotene, astaxanthin and lutein that have multiple therapeutic properties. Lately many studies have focused on optimization of pigment extraction and increase in pigment content [37], [41]. C. vulgaris biomass has been used as a biofertilizer with good results [28].

C. vulgaris has demonstrated high potential for wastewater treatment. Rapid growth and high nutrient removal have been shown in various wastewater streams such as urban [55], industrial [61] and agricultural wastewater [56], [71]. C. vulgaris has shown some remarkably high ammonia nitrogen and total nitrogen removal rates over $96 \%$ and total phosphorus removal 69 to $98 \%$ in various wastewaters [55], [56], [71], [72]. Efficiency of heavy metal removal depends on the species, $C$. vulgaris has shown good removal of cadmium, copper and zinc [73].

\subsection{Chlorella sorokiniana}

C. sorokiniana is the most heat and high light resistant species in the genus Chlorella [74]. Species can tolerate temperatures up to $42{ }^{\circ} \mathrm{C}$ [17], [75]; however, optimal growth temperatures seem to depend on a combination of several biotic and abiotic factors, as reported optimal temperatures vary across studies and are in range from $30{ }^{\circ} \mathrm{C}$ to $40{ }^{\circ} \mathrm{C}$ [74], [76], [77]. Still, the most frequently reported optimal temperatures are $36{ }^{\circ} \mathrm{C}-38{ }^{\circ} \mathrm{C}[78]-$ [80]. The performance under extreme environmental conditions was demonstrated by Morita et al., who observed good photosynthetic productivity even at $46.5{ }^{\circ} \mathrm{C}$ that was coupled with high light intensity [77]. The common growth temperature which is optimal for some other microalgae strains is not suitable for $C$. sorokiniana. Cuaresma Franko found that temperature below $20^{\circ} \mathrm{C}$ had an inhibitory effect on microalga growth [79]. C. sorokiniana can withstand not only high temperatures but also high intensity light up to $2500 \mu \mathrm{mol} \mathrm{m}^{-2} \mathrm{~s}^{-1}$ [74]. Testing five different light intensities of 100, 200, 400, 600 and $750 \mu \mathrm{mol} \mathrm{m} \mathrm{m}^{-2} \mathrm{~s}^{-1}$, Tan found that at $750 \mu \mathrm{mol} \mathrm{m} \mathrm{m}^{-2} \mathrm{~s}^{-1}$ resulted in the best growth, indicating higher light requirements than other common microalgae species [31].

Considering tolerance to high temperature and light intensity $C$. sorokiniana can be a good candidate strain for biomass production in outdoor cultivation systems in regions with high insolation. Open ponds tend to reach high temperatures and light intensity especially during mid-day [81], often exceeding the optimum temperature of the strain particularly in the upper layer of the water. Therefore, a heat resistant strain is preferred in these conditions. Temperature has an impact also on lipid productivity. Li observed that highest lipid content of C. sorokiniana was reached at $30{ }^{\circ} \mathrm{C}(37 \%)$, however the highest lipid yield at $37{ }^{\circ} \mathrm{C}$ [80]. 
C. sorokiniana has substantial tolerance to high nutrient concentrations in wastewater and is able to remove up to $99 \%$ of nitrogen and phosphorus depending on the initial concentration [82]. Microalga has exhibited good capability of ammonium removal under extreme temperature and light conditions [74]. Kim [49] found that $C$. sorokiniana exhibited the best growth rate and nutrient removal while cultivated under heterotrophic conditions with glucose as a carbon source compared to autotrophic and mixotrophic conditions. Moreover, the growth rate was more than two-fold higher for heterotrophic cultures than autotrophic [49]. However, Li found that mixotrophy resulted in considerably higher biomass concentration, growth rate and lipid productivity than either heterotrophic or mixotrophic cultivation [83]. Rosenberg reported a rapid nine-hour heterotrophic doubling time [84], while Rai found a remarkable doubling time of $2 \mathrm{~h} 9 \mathrm{~min}$ under mixotrophic conditions [70].

\subsection{Chlorella protothecoides (Auxenochlorella protothecoides)}

C. protothecoides is a robust, fast growing species able to grow in various wastewaters [57], [72]. The species has received most attention regarding biomass production under various cultivation modes, specifically mixotrophic and heterotrophic conditions to increase lipid production. Furthermore, extraction of value-added compounds, mainly pigments, has been a focus of C. protothecoides cultivation [85], [86]. This species is a valuable source of bioactive compounds. Particular attention has been paid to extraction of pigments. High concentrations of carotenoids and chlorophylls have been found under phototrophic and mixotrophic growth modes. Higher cellular accumulation of pigments has been observed at phototrophic mode, however concentration per unit volume was higher under mixotrophic growth [85]. Salt and light stress are known to induce the carotenogenesis process in $C$. protothecoides allowing accumulation of astaxanthin and lutein/zeaxanthin [85]. C. protothecoides CS41 had the highest biomass yield and lutein content when seven Chlorella strains were compared (3 strains of C. pyrenoidosa, three strains of C. vulgaris and one strain of C. protothecoides) under heterotrophic conditions using glucose as a carbon source [87].

Li was able to achieve $48.7 \%$ lipid content in heterotrophic conditions in $750 \mathrm{~L}$ bioreactor [88]. In the same study, successful scale-up was demonstrated, heterotrophic culture density reached $15.5 \mathrm{~g} \mathrm{~L}^{-1}$ in $5 \mathrm{~L}, 12.8 \mathrm{~g} \mathrm{~L}^{-1}$ in $750 \mathrm{~L}$, and $14.2 \mathrm{~g} \mathrm{~L}^{-1}$ in $11000 \mathrm{~L}$ bioreactors. Shi succeeded to reach remarkable $48 \mathrm{~g} \mathrm{~L}^{-1}$ biomass yield in a $3.7 \mathrm{~L}$ fermenter and $45.8 \mathrm{~g} \mathrm{~L}^{-1}$ in upscaled $30 \mathrm{~L}$ fermenter [89]. Moreover, lipid content reached $57.8 \%$ in batch and $55.2 \%$ in fed-batch culture of heterotrophic C. protothecoides grown on glucose [63].

Studies indicate that $C$. protothecoides can grow in different wastewaters with similar performance and is resistant to high chemical content. Microalga showed good performance in raw, untreated urban wastewaters exhibiting high growth rate and efficient removal of $\mathrm{N}$ and $\mathrm{P}$ [90]. Results showed that endogenous bacterial contamination did not limit algal growth rate. C. protothecoides demonstrates a high growth rate and efficient removal of NH4+-N also from various anaerobic digestion effluents [72]. An additional benefit of this species is the significantly faster settling of cells compared to $C$. vulgaris that is particularly important for biomass harvesting [72].

\subsection{Chlorella kessleri (Parachlorella kessleri)}

C. kessleri cells are larger than C. vulgaris [55] that might be advantage for biomass harvesting. C. kessleri has been studied for its potential for biodiesel production and extraction of high value products. TAG accumulation in $C$. kessleri is induced by high light intensity, hyperosmosis and nutrient limitation. Hayashi showed that low temperature could 
also stimulate TAG accumulation but only for a limited time [91]. Moreover, the same study demonstrated very high TAG accumulation up to $48.5 \%$ in $C$. kessleri cells due to synergetic effects of hyperosmosis, nutrient-limitation, increased light intensity and low temperature. A notable $54.7 \%$ total fatty acid content was achieved in mixotrophic cultivation with $300 \mathrm{mmol} \mathrm{L}^{-1}$ glucose under nitrate depletion conditions that was about 5-hold increase compared to autotrophic cultures [92]. Some high value bioactive compounds have been extracted from $C$. kessleri biomass. Although lutein content in $C$. kessleri cells is not significant, the strain is a natural source of astaxanthin. Soares reported nearly $23 \mathrm{mg} \mathrm{g}^{-1}$ astaxanthin in photoautotrophic cultivation conditions [93]. Encouraging results have been achieve for its application in wastewater treatment. Biomass production of $C$. kessleri in wastewater is reported to be comparable to that of $C$. vulgaris [55]. C. kessleri has showed more tolerance to some pollutants, like chromium, copper and herbicide than other microalgae species [92]. It was capable to remove $94 \%$ of chemical oxygen demand and $96 \%$ of NH4+-N and $\mathrm{P}$ from aquaculture wastewater just in 3 days and was superior to Scenedesmus spp. and C. vulgaris [94]. Likewise, C. kessleri has demonstrated high uptake of $\mathrm{N}$ and $\mathrm{P}$ also in urban wastewater showing more than $96 \%$ and $99 \%$ removal, respectively [55].

\subsection{Chlorella minutissima}

C. minutissima is a high $\mathrm{CO}_{2}$-tolerant microalga with easy cultivation and fast growth [64]. It has small unicellular spherical cells from $2 \mu \mathrm{m}$ to $4 \mu \mathrm{m}$ in diameter when grown in synthetic medium and larger cells, from $2 \mu \mathrm{m}$ to $8 \mu \mathrm{m}$ in medium with organic carbon [95]. $C$. minutissima is tolerant to pollution and fluctuating environmental conditions [95]. It can grow at exceptionally wide $\mathrm{pH}$ range from 4 to 10 , although growth at $\mathrm{pH} 4-5$ is strictly constrained. The optimum growth has been observed at $\mathrm{pH} 7$ [95]. Tolerance to a wide $\mathrm{pH}$ range is especially valuable in open raceway pond cultivation where control of environmental parameters is not always straightforward. Moreover, another advantage for outdoor cultivation is dominance over other microorganisms diminishing the risk of contamination with fungi, bacteria and other algae [95].

It has been noted that C. minutissima has a fatty acid profile desirable for biodiesel production [64]. Moreover, nitrogen starvation is an effective method for enhancement of total lipid and TAG content in C. minutissima [64]. Tang found that neither light source nor intensity or photoperiod had a significant effect on fatty acid methyl esters (FAME) content [64]. Lipid content can reach $57 \%$ when cultivated in low nitrogen medium [65].

C. minutissima can grow in photoautotrophic, heterotrophic and mixotrophic conditions, however, Bhatnagar found that growth in heterotrophic conditions was significantly lower than that of autotrophic whatever the carbon source was used [95]. C. minutissima can utilize several carbon sources, such as glycerol, glucose, succinate, molasses and press mud [96]. According to Bhatnagar, glucose is the preferred carbon source for mixotrophic growth and resulted in synergistic growth in the presence of light [95]. Other study proposed that glycerin is the optimal carbon source however, glucose was not tested in this study [97]. $C$. minutissima shows halotolerance up to $3 \% \mathrm{NaCl}$ suggesting potential application in treating municipal wastewaters that are often characterized by high sodium content [95]. Bhatnagar demonstrated that $C$. minutissima exhibits better growth on diluted wastewater (up to $75 \%$ ) compared to synthetic BG-11 medium [95]. Moreover, $50 \%$ wastewater supported $146 \%$ better growth than BG-11 medium indicating high potential of this microalga for wastewater treatment 


\section{CONClusion}

Data on the growth rate and productivity of microalgae reported in the literature varies extensively. The observed dispersion of data is mainly due to cultivation conditions of the microalgae. Growth rate, biomass productivity and lipid content of a microalgal species are parameters particularly difficult to compare across studies as they depend highly on cultivation conditions such as light intensity, temperature, photoperiod, cultivation mode (batch, semi-batch, continuous), metabolic conditions (phototrophic, heterotrophic or mixotrophic growth), scale of the cultivation, growth media and nutrients used (synthetic growth media, wastewater etc.). All these parameters make comparison of various experiments and microalgae strains difficult. Every experiment is carried out in unique conditions and are generally not comparable across studies. Thus, it is of great importance to compare different microalgal strains in one study under the same culturing conditions. There are not enough studies comparing several productive microalgae strains simultaneously to get comprehensive comparable results for the selection of the most promising strains. Another aspect to consider is the degree of variation between strains of the same species. Specific strains have been isolated from different habitats under various environmental conditions and can therefore exhibit different responses to various conditions.

Cosmopolitan species of the genus Chlorella can be found in diverse habitats throughout the world. A number of key features potentially make Chlorella spp. highly beneficial for large-scale biomass production. Fast growth rate, low nutritional requirements, low sensitivity to contamination and flexibility to fluctuating environments, ability to grow in autotrophic, heterotrophic and mixotrophic conditions make Chlorella spp. highly useful for outdoor cultivation coupled with wastewater treatment. Results of the present study demonstrate that Chlorella spp. are suitable feedstock for bioenergy production. Some studies have reported very high growth rates of various Chlorella species supporting the goal of high biomass yield. $C$. vulgaris is often receiving the highest rating among microalgae strains in terms of growth rate, resistance to pollution and lipid productivity, moreover it can withstand wide temperature range showing its usefulness in outdoor conditions. Results indicate that $C$. vulgaris is not only a widespread model organism but holds real potential for bioenergy production. C. sorokiniana shows potential at locations with warmer climates and high insolation due to its resistance to high temperature and light intensity. Several studies have shown that Chlorella species are natural inhabitants of wastewater ponds indicating their potential in wastewater treatment. Indeed, all Chlorella species studied are suitable for cultivation in various wastewater streams showing high nutrient removal rates and resistance to contaminants. However, the suitable dilution rate of a stronger wastewater must be obtained to exclude the inhibitory effect of excessive ammonium level. Furthermore, Chlorella is a source of many bioactive compounds with commercial value that can be coextracted to further increase the viability of microalgal bioenergy. The most promising value-added products are chlorophylls, lutein, $\beta$-carotene and lipids. The drawback for biorefinery is a thick resistant cell wall that makes downstream processing of algal biomass difficult. On the other hand, a thick cell wall makes Chlorella shear resistant and is an advantage for cultivation in bioreactors. Numerous studies show that Chlorella species hold great potential for a large-scale biomass production, however optimization of cultivation conditions is of primary importance to achieve high biomass yield and increase the content of high value compounds 


\section{ACKNOWLEDGEMENT}

This research is funded by the Latvian Council of Science, project "Integrated $\mathrm{CO}_{2}$ biofilter and microalgae biomass production technology for biogas plants using novel Stacked Modular Open Raceway Pond approach (SMORP)", project No. LZP-2018/1-0232.

\section{FLPP}

\section{REFERENCES}

[1] Brennan L., Owende P. Biofuels from microalgae-A review of technologies for production, processing, and extractions of biofuels and co-products. Renewable and. Sustainable Energy Reviews 2010:14:(2):557-577. https://doi.org/10.1016/j.rser.2009.10.009

[2] Safi C., Zebib B., Merah O., Pontalier P. Y., Vaca-Garcia C. Morphology, composition, production, processing and applications of Chlorella vulgaris: A review. Renewable and Sustainable Energy Reviews 2014:35:265-278. https://doi.org/10.1016/j.rser.2014.04.007

[3] Amer L., Adhikari B., Pellegrino J. Technoeconomic analysis of five microalgae-to-biofuels processes of varying complexity. Bioresource Technology 2011:102(20):9350-9359. https://doi.org/10.1016/j.biortech.2011.08.010

[4] Barsanti L., Gualtieri P. Is exploitation of microalgae economically and energetically sustainable. Algal Research 2017:31:107-115. https://doi.org/10.1016/j.algal.2018.02.001

[5] Davis R., Aden A., Pienkos P. T. Techno-economic analysis of autotrophic microalgae for fuel production. Applied Energy 2011:88(10):3524-3531. https://doi.org/10.1016/j.apenergy.2011.04.018

[6] Smith V. H., Sturm B. S. M., deNoyelles F. J., Billings S. A. The ecology of algal biodiesel production. Trends in Ecology and Evolution 2010:25(5):301-309. https://doi.org/10.1016/j.tree.2009.11.007

[7] Chiaramonti D. et al. Review of energy balance in raceway ponds for microalgae cultivation: Re-thinking a traditional system is possible. Applied Energy 2013:102:101-111. https://doi.org/10.1016/j.apenergy.2012.07.040

[8] Chew K. W. et al. Microalgae biorefinery: High value products perspectives. Bioresource Technology 2017:229:5362. https://doi.org/10.1016/j.biortech.2017.01.006

[9] Koutra E., Economou C. N., Tsafrakidou P., Kornaros M. Bio-Based Products from Microalgae Cultivated in Digestates. Trends in Biotechnology 2018:36(8):819-833. https://doi.org/10.1016/j.tibtech.2018.02.015

[10] Guiry M. D. How many species of algae are there? Journal of Phycology 2012:48(5):1057-1063. https://doi.org/10.1111/j.1529-8817.2012.01222.x

[11] Borowitzka M. A., Moheimani N. R. (Eds.) Algae for Biofuels and Energy. Springer, 2013. https://doi.org/10.1007/978-94-007-5479-9

[12] Richmond A. Handbook of Microalgal Culture: Biotechnology and Applied Phycology. Oxford: Blackwell Science, 2004.

[13] Iwamoto H. Industrial Production of Microalgal Cell-mass and Secondary Products - Major Industrial Species. In Handbook of Microalgal Culture: Biotechnology and Applied Phycology, A. Richmond, Ed. Blackwell Science, 2004, pp. 255-263.

[14] Champenois J., Marfaing H., Pierre R. Review of the taxonomic revision of Chlorella and consequences for its food uses in Europe. Journal of Applied Phycology 2015:27(5):1845-1851. https://doi.org/10.1007/s10811-014-0431-2

[15] Zhou W., Li Y., Min M., Hu B., Chen P., Ruan R. Local bioprospecting for high-lipid producing microalgal strains to be grown on concentrated municipal wastewater for biofuel production. Bioresource Technology 2011:102(13):6909 6919. https://doi.org/10.1016/j.biortech.2011.04.038

[16] Maxwell D. P., Falk S., Trick C. G., Huner N. P. A. Growth at low temperature mimics high-light acclimation in Chlorella vulgaris. Plant Physiology 1994:105(2):535-543. https://doi.org/10.1104/pp.105.2.535

[17] Kessler E. Upper limits of temperature for growth in Chlorella (Chlorophyceae). Plant Systematics and Evolution 1985:151(1-2):67-71. https://doi.org/10.1007/BF02418020

[18] Michael A. Borowitzka. Species and Strain Selection. In Algae for Biofuels and Energy Ed. Springer, 2013, pp. 7689. https://doi.org/10.1007/978-94-007-5479-9_4

[19] Liu J., Sun Z., Gerken H., Liu Z., Jiang Y., Chen F. Chlorella zofingiensis as an alternative microalgal producer of astaxanthin: Biology and industrial potential. Marine Drugs 2014:12(6):3487-3515. https://doi.org/10.3390/md12063487

[20] Huss V. A. R. et al. Biochemical Taxonomy and Molecular Phylogeny of the Genus Chlorella Sensu Lato (Chlorophyta). Journal Phycology 1999:35(3):587-598. https://doi.org/10.1046/j.1529-8817.1999.3530587.x 
[21] Kumar K., Mishra S. K., Shrivastav A., Park M. S., Yang J. W. Recent trends in the mass cultivation of algae in raceway ponds. Renewable and Sustainable Energy Reviews 2015:51:875-885. https://doi.org/10.1016/j.rser.2015.06.033

[22] Krienitz L., Hegewald E. H., Hepperle D., Huss V. A. R., Rohr T., Wolf M. Phylogenetic relationship of Chlorella and Parachlorella gen. nov. (Chlorophyta, Trebouxiophyceae). Phycologia 2004:43(5):529-542. https://doi.org/10.2216/i0031-8884-43-5-529.1

[23] Bock C., Krienitz L., Pröschold T. Taxonomic reassessment of the genus Chlorella (Trebouxiophyceae) using molecular signatures (barcodes), including description of seven new species. Fottea 2011:11(2):293-312. https://doi.org/10.5507/fot.2011.028

[24] Krienitz L., Huss V. A. R., Bock C. Chlorella: 125 years of the green survivalist. Trends in Plant Science 2015:20(2):67-69. https://doi.org/10.1016/i.tplants.2014.11.005

[25] Kessler E., Huss V. A. R. Comparative Physiology and Biochemistry and Taxonomic Assignment of the Chlorella (Chlorophyceae) Strains of the Culture Collection of the University of Texas at Austin. Journal of Phycology 1992:28(4):550-553. https://doi.org/10.1111/j.0022-3646.1992.00550.x

[26] Santhoshkumar K., Prasanthkumar S., George Ray J. Biomass Productivity and Fatty Acid Composition of Chlorella lobophora V M Andreyeva, a Potential Feed Stock for Biodiesel Production. American Journal of Plant Science 2015:6(15):2453-2460. https://doi.org/10.4236/ajps.2015.615247

[27] Santhosh Kumar K., Prasanthkumar S., Ray J. G. Biomass yield, oil productivity and fatty acid profile of Chlorella lobophora cultivated in diverse eutrophic wastewaters. Biocatalysis and Agricultural Biotechnology 2017:11:338-344. https://doi.org/10.1016/j.bcab.2017.08.006

[28] Bhalamurugan G. L., Valerie O., Mark L. Valuable bioproducts obtained from microalgal biomass and their commercial applications: A review. Environmental Engineering Research 2018:23(3):229-241. https://doi.org/10.4491/eer.2017.220

[29] Mobin S., Alam F. Some Promising Microalgal Species for Commercial Applications: A review. Energy Procedia, 2017:110:510-517. https://doi.org/10.1016/j.egypro.2017.03.177

[30] Becker E. W. Micro-algae as a source of protein. Biotechnology Advances 2007:25(2):207-210. https://doi.org/10.1016/j.biotechadv.2006.11.002

[31] Tan C. H. et al. Examination of indigenous microalgal species for maximal protein synthesis. Biochemical Engineering Journal 2020:154:107425. https://doi.org/10.1016/j.bej.2019.107425

[32] Atsushi Hirano Y. O., Ueda R., Hirayama S. $\mathrm{CO}_{2}$ fixation and ethanol production with microalgal photosynthesis and intracellular anaerobic fermentation. Energy 1997:22(2-3):137-142. https://doi.org/10.1016/S0360-5442(96)00123-5

[33] Mizuno Y. et al. Sequential accumulation of starch and lipid induced by sulfur deficiency in Chlorella and Parachlorella species. Bioresource Technology 2013:129:150-155. https://doi.org/10.1016/j.biortech.2012.11.030

[34] Deviram G., Mathimani T. Anto S., Ahamed T. S., Ananth D. A., Pugazhendhi A. Applications of microalgal and cyanobacterial biomass on a way to safe, cleaner and a sustainable environment. Journal of Cleaner Production 2020:253:119770. https://doi.org/10.1016/j.jclepro.2019.119770

[35] Othman R., Noh N. H., Hatta F. A. M., Jamaludin M. A. Natural Carotenoid Pigments of 6 Chlorophyta Freshwater Green Algae Species. Lifescience Global 2018:1-5. https://doi.org/10.6000/1927-5951.2018.08.01.1

[36] Fernández-Sevilla J. M., Acién Fernández F. G., Molina Grima E. Biotechnological production of lutein and its applications. Applied Microbiology and Biotechnology 2010:86(1):27-40. https://doi.org/10.1007/s00253-009-2420-y

[37] D’Este M., De Francisci D., Angelidaki I. Novel protocol for lutein extraction from microalga Chlorella vulgaris. Biochemical Engineering Journal 2017:127:175-179. https://doi.org/10.1016/j.bej.2017.06.019

[38] Chen C. Y., Liu C. C. Optimization of lutein production with a two-stage mixotrophic cultivation system with Chlorella sorokiniana MB-1. Bioresource Technology 2018:262:74-79. https://doi.org/10.1016/j.biortech.2018.04.024

[39] Wei D., Chen F., Chen G., Zhang X. W., Liu L. J., Zhang H. Enhanced production of lutein in heterotrophic Chlorella protothecoides by oxidative stress. Science in China Series C: Life Sciences 2008:51(12):1088-1093. https://doi.org/10.1007/s11427-008-0145-2

[40] Dineshkumar R., Subramanian G., Dash S. K., Sen R. Development of an optimal light-feeding strategy coupled with semi-continuous reactor operation for simultaneous improvement of microalgal photosynthetic efficiency, lutein production and $\mathrm{CO}_{2}$ sequestration. Biochemical Engineering Journal 2016:113:47-56. https://doi.org/10.1016/j.bej.2016.05.011

[41] McClure D. D., Nightingale J. K., Luiz A., Black S., Zhu J., Kavanagh J. M. Pilot-scale production of lutein using Chlorella vulgaris. Algal Research 2019:44:101707. https://doi.org/10.1016/j.algal.2019.101707

[42] Lin J. H., Lee D. J., Chang J. S. Lutein production from biomass: Marigold flowers versus microalgae. Bioresource Technology 2015:184:421-428, 2015. https://doi.org/10.1016/j.biortech.2014.09.099

[43] Barkia I., Saari N., Manning S. R. Microalgae for high-value products towards human health and nutrition. Marine Drugs 2019:17(5):1-29. https://doi.org/10.3390/md17050304

[44] Wang X., Zhang X. Separation, antitumor activities, and encapsulation of polypeptide from Chlorella pyrenoidosa. Biotechnology Progress 2013:29(3):681-687. https://doi.org/10.1002/btpr.1725

[45] Cai T., Park S. Y., Li Y. Nutrient recovery from wastewater streams by microalgae: Status and prospects. Renewable and Sustainable Energy Reviews 2013:19:360-369. https://doi.org/10.1016/j.rser.2012.11.030 
[46] Abdel-Raouf N., Al-Homaidan A. A., Ibraheem I. B. M. Microalgae and wastewater treatment. Saudi Journal of Biologial Sciences 2012:19(3):257-275. https://doi.org/10.1016/j.sjbs.2012.04.005

[47] Lowrey J., Brooks M. S., McGinn P. J. Heterotrophic and mixotrophic cultivation of microalgae for biodiesel production in agricultural wastewaters and associated challenges - a critical review. Journal of Applied Phycology 2015:27(4):1485-1498. https://doi.org/10.1007/s10811-014-0459-3

[48] Li Y., Zhou W., Hu B., Min M., Chen P., Ruan R. R. Integration of algae cultivation as biodiesel production feedstock with municipal wastewater treatment: Strains screening and significance evaluation of environmental factors. Bioresource Technology 2011:102(23):10861-10867. https://doi.org/10.1016/j.biortech.2011.09.064

[49] Kim S., eun Park J., Cho Y. B., Hwang S. J. Growth rate, organic carbon and nutrient removal rates of Chlorella sorokiniana in autotrophic, heterotrophic and mixotrophic conditions. Bioresource Technology 2013:144:8-13. https://doi.org/10.1016/j.biortech.2013.06.068

[50] Scarsella M., Belotti G., De Filippis P., Bravi M. Study on the optimal growing conditions of Chlorella vulgaris in bubble column photobioreactors. Chem. Eng. Trans 2010:20:85-90.

[51] Babaei A., Mehrnia M. R., Shayegan J., Sarrafzadeh M. H., Amini E. Evaluation of Nutrient Removal and Biomass Production Through Mixotrophic, Heterotrophic, and Photoautotrophic Cultivation of Chlorella in Nitrate and Ammonium Wastewater. International Journal of Environmental Research 2018:12(2):167-178. https://doi.org/10.1007/s41742-018-0077-Z

[52] Sharma A. K., Sahoo P. K., Singhal S., Patel A. Impact of various media and organic carbon sources on biofuel production potential from Chlorella spp. 3 Biotech 2016:6(2):1-12. https://doi.org/10.1007/s13205-016-0434-6

[53] Palmer C. M. A composite rating of algae tolerating organic pollution. Journal of Phycology 1969:5(1):78-82. https://doi.org/10.1111/j.1529-8817.1969.tb02581.x

[54] Wang L. et al. Anaerobic digested dairy manure as a nutrient supplement for cultivation of oil-rich green microalgae Chlorella sp. Bioresource Technology 2010:101(8):2623-2628. https://doi.org/10.1016/j.biortech.2009.10.062

[55] Caporgno M. P. et al. Microalgae cultivation in urban wastewater: Nutrient removal and biomass production for biodiesel and methane. Algal Research 2015:10:232-239. https://doi.org/10.1016/j.algal.2015.05.011

[56] Franchino M., Comino E., Bona F., Riggio V. A. Growth of three microalgae strains and nutrient removal from an agro-zootechnical digestate. Chemosphere 2013:92(6):738-744. https://doi.org/10.1016/j.chemosphere.2013.04.023

[57] Oberholster P. J., Cheng P. H., Genthe B., Steyn M. The environmental feasibility of low-cost algae-based sewage treatment as a climate change adaption measure in rural areas of SADC countries. Journal of Applied Phycology 2019:31(1):355-363. https://doi.org/10.1007/s10811-018-1554-7

[58] Palmer C. M. Algae in american sewage stabilization's ponds. Rev. Microbiol. 1974:5(4):75-80.

[59] Ayre J. M., Moheimani N. R., Borowitzka M. A. Growth of microalgae on undiluted anaerobic digestate of piggery effluent with high ammonium concentrations. Algal Research 2017:24:218-226. https://doi.org/10.1016/j.algal.2017.03.023

[60] Álvarez-Díaz P. D., Ruiz J., Arbib Z., Barragán J., Garrido-Pérez M. C., Perales J. A. Freshwater microalgae selection for simultaneous wastewater nutrient removal and lipid production. Algal Research 2017:24:477-485. https://doi.org/10.1016/j.algal.2017.02.006

[61] Chinnasamy S., Bhatnagar A., Hunt R. W., Das K. C. Microalgae cultivation in a wastewater dominated by carpet mill effluents for biofuel applications. Bioresource Technology 2010:101(9):3097-3105. https://doi.org/10.1016/j.biortech.2009.12.026

[62] Mata T. M., Martins A. A., Caetano N. S. Microalgae for biodiesel production and other applications: A review. Renewable and Sustainable Energy Reviews 2010:14(1):217-232. https://doi.org/10.1016/j.rser.2009.07.020

[63] Xiong W., Li X., Xiang J., Wu Q. High-density fermentation of microalga Chlorella protothecoides in bioreactor for microbio-diesel production. Applied Microbiology and Biotechnology 2008:78(1):29-36. https://doi.org/10.1007/s00253-007-1285-1

[64] Tang H., Chen M., Garcia M. E. D., Abunasser N., Ng K. Y. S., Salley S. O. Culture of microalgae Chlorella minutissima for biodiesel feedstock production. Biotechnology and Bioengineering 2011:108(10):2280-2287. https://doi.org/10.1002/bit.23160

[65] Illman A. M., Scragg A. H., Shales S. W. Increase in Chlorella strains calorific values when grown in low nitrogen medium. Enzyme and Microbial Technology 2000:27(8):631-635. https://doi.org/10.1016/S0141-0229(00)00266-0

[66] dos Santos R. R., Kunigami C. N., Gomes Aranda D. A., Luz Lapa Teixeira C. M. Assessment of triacylglycerol content in Chlorella vulgaris cultivated in a two-stage process. Biomass and Bioenergy 2016:92:55-60. https://doi.org/10.1016/j.biombioe.2016.05.014

[67] Serra-Maia R., Bernard O., Gonçalves A., Bensalem S., Lopes F. Influence of temperature on Chlorella vulgaris growth and mortality rates in a photobioreactor. Algal Research 2016:18:352-359. https://doi.org/10.1016/j.algal.2016.06.016

[68] Bhola V., Desikan R., Santosh S. K., Subburamu K., Sanniyasi E., Bux F. Effects of parameters affecting biomass yield and thermal behaviour of Chlorella vulgaris. Journal of Bioscience and Bioengineering 2011:111(3):377-382. https://doi.org/10.1016/j.jbiosc.2010.11.006 
[69] Gong Q., Feng Y., Kang L., Luo M., Yang J. Effects of light and pH on cell density of Chlorella vulgaris. Energy Procedia 2014:61:2012-2015. https://doi.org/10.1016/j.egypro.2014.12.064

[70] Rai U., Deshar G., Rai B., Bhattarai K., Dhakal R., Rai S. Isolation and Culture Condition Optimization of Chlorella vulgaris. Nepal Journal of Science and Technology 2014:14(2):43-48. https://doi.org/10.3126/njst.v14i2.10414

[71] Kwon G., Nam J.-H., Kim D.-M., Song C., Jahng D. Growth and nutrient removal of Chlorella vulgaris in ammoniareduced raw and anaerobically-digested piggery wastewaters. Environmental Engineering Research 2020:25(2):135146. https://doi.org/10.4491/eer.2018.442

[72] Yu H., Kim J., Lee C. Nutrient removal and microalgal biomass production from different anaerobic digestion effluents with Chlorella species. Scientific Reports 2019:9(1):1-13. https://doi.org/10.1038/s41598-019-42521-2

[73] Molazadeh M., Ahmadzadeh H., Pourianfar H. R., Lyon S., Rampelotto P. H. The use of microalgae for coupling wastewater treatment with $\mathrm{CO}_{2}$ biofixation. Frontiers in Bioengineering and Biotechnology 2019:7. https://doi.org/10.3389/fbioe.2019.00042

[74] de-Bashan L. E., Trejo A., Huss V. A. R., Hernandez J. P., Bashan Y. Chlorella sorokiniana UTEX 2805, a heat and intense, sunlight-tolerant microalga with potential for removing ammonium from wastewater. Bioresource Technology 2008:99(11):4980-4989. https://doi.org/10.1016/j.biortech.2007.09.065

[75] Li S., Luo S., Guo R. Efficiency of $\mathrm{CO}_{2}$ fixation by microalgae in a closed raceway pond. Bioresource Technology 2013:136:267-272. https://doi.org/10.1016/j.biortech.2013.03.025

[76] Kumar K., Dasgupta C. N., Das D. Cell growth kinetics of Chlorella sorokiniana and nutritional values of its biomass. Bioresource Technology 2014:167:358-366. https://doi.org/10.1016/j.biortech.2014.05.118

[77] Morita M., Watanabe Y., Saiki A. H. High photosynthetic productivity of green microalga Chlorella sorokiniana. Applied Biochemistry and Biotechnology 2000:87:203-218. https://doi.org/10.1385/ABAB:87:3:203

[78] Lammers P. J. et al. Review of the cultivation program within the National Alliance for Advanced Biofuels and Bioproducts. Algal Research 2017:22:166-186. https://doi.org/10.1016/j.algal.2016.11.021

[79] Franco M. C., Buffing M. F., Janssen M., Lobato C. V., Wijffels R. H. Performance of Chlorella sorokiniana under simulated extreme winter conditions. Journal of Applied Phycology 2012:24(4):693-699. https://doi.org/10.1007/s10811-011-9687-y

[80] Li T., Zheng Y., Yu L., Chen S. High productivity cultivation of a heat-resistant microalga Chlorella sorokiniana for biofuel production. Bioresource Technology 2013:131:60-67. https://doi.org/10.1016/i.biortech.2012.11.121

[81] Park J. B. K., Craggs R. J., Shilton A. N. Wastewater treatment high rate algal ponds for biofuel production. Bioresource Technology 2011:102(1):35-42. https://doi.org/10.1016/j.biortech.2010.06.158

[82] Murwanashyaka T., Shen L., Ndayambaje J. D., Wang Y., He N., Lu Y. Kinetic and transcriptional exploration of Chlorella sorokiniana in heterotrophic cultivation for nutrients removal from wastewaters. Algal Research 2017:24:467-476. https://doi.org/10.1016/j.algal.2016.08.002

[83] Li T., Zheng Y., Yu L., Chen S. Mixotrophic cultivation of a Chlorella sorokiniana strain for enhanced biomass and lipid production. Biomass and Bioenergy 2014:66:204-213. https://doi.org/10.1016/j.biombioe.2014.04.010

[84] Rosenberg J. N., Kobayashi N., Barnes A., Noel E. A., Betenbaugh M. J., Oyler G. A. Comparative analyses of three Chlorella species in response to light and sugar reveal distinctive lipid accumulation patterns in the microalga $C$. sorokiniana. PLoS One 2014:9(4). https://doi.org/10.1371/journal.pone.0092460

[85] Ribeiro J. E. S. et al. Production of Chlorella protothecoides biomass, chlorophyll and carotenoids using the dairy industry by-product scotta as a substrate. Biocatalysis and Agricultural Biotechnology 2017:11:207-213. https://doi.org/10.1016/j.bcab.2017.07.007

[86] Feng X., Walker T. H., Bridges W. C., Thornton C., Gopalakrishnan K. Biomass and lipid production of Chlorella protothecoides under heterotrophic cultivation on a mixed waste substrate of brewer fermentation and crude glycerol. Bioresource Technology 2014:166:17-23. https://doi.org/10.1016/j.biortech.2014.03.120

[87] Shi X. M., Chen F., Yuan J. P., Chen H. Heterotrophic production of lutein by selected Chlorella strains. Journal of Applied Phycology 1997:9(5):445-450. https://doi.org/10.1023/A:1007938215655

[88] Xiufeng Li Q. W., Han Xu. Large-Scale Biodiesel Production From Microalga Chlorella protothecoides Through Heterotrophic Cultivation in Bioreactors. Biotechnology and Bioengineering 2007:98(4):764-771. https://doi.org/10.1002/bit.21489

[89] Shi X. M., Jiang Y., Chen F. High-yield production of lutein by the green microalga Chlorella protothecoides in heterotrophic fed-batch culture. Biotechnology Progress 2002:18(4):723-727. https://doi.org/10.1021/bp0101987

[90] Ramos Tercero E. A., Sforza E., Morandini M., Bertucco A. Cultivation of Chlorella protothecoides with urban wastewater in continuous photobioreactor: Biomass productivity and nutrient removal. Applied Biochemistry and Biotechnology 2014:172(3):1470-1485. https://doi.org/10.1007/s12010-013-0629-9

[91] Hayashi T., Otaki R., Hirai K., Tsuzuki M., Sato N. Optimization of seawater-based triacylglycerol accumulation in a freshwater green alga, Chlorella kessleri, through simultaneous imposition of lowered-temperature and enhanced-light intensity. Algal Research 2017:28:100-107. https://doi.org/10.1016/j.algal.2017.10.016

[92] Wang Y., Chen T., Qin S. Differential fatty acid profiles of Chlorella kessleri grown with organic materials. Chemical Technology and Biotechnology 2013:88(4):651-657. https://doi.org/10.1002/jctb.3881 
[93] Soares A. T., da Costa D. C., Vieira A. A. H., Antoniosi Filho N. R. Analysis of major carotenoids and fatty acid composition of freshwater microalgae. Heliyon 2019. https://doi.org/10.1016/j.heliyon.2019.e01529

[94] Liu Y., Lv J., Feng J., Liu Q., Nan F., Xie S. Treatment of real aquaculture wastewater from a fishery utilizing phytoremediation with microalgae. Chemical Technology and Biotechnology 2019:94(3):900-910. https://doi.org/10.1002/jctb.5837

[95] Bhatnagar A., Bhatnagar M., Chinnasamy S., Das K. C. Chlorella minutissima - A promising fuel alga for cultivation in municipal wastewaters. Applied Biochemistry and Biotechnology 2010:161(1-8):523-536. https://doi.org/10.1007/s12010-009-8771-0

[96] Gautam K., Pareek A., Sharma D. K. Biochemical composition of green alga Chlorella minutissima in mixotrophic cultures under the effect of different carbon sources. Journal of Bioscience and Bioengineering 2013:116(5):624-627. https://doi.org/10.1016/j.jbiosc.2013.05.014

[97] Li Z. S., Yuan H. L., Yang J. S., Li B. Z. Optimization of the biomass production of oil algae Chlorella minutissima UTEX2341. Bioresource Technology 2011:102(19):9128-9134. https://doi.org/10.1016/j.biortech.2011.07.004

[98] Daliry S., Hallajisani A., Roshandeh J. M., Nouri H., Golzary A. Investigation of optimal condition for Chlorella vulgaris microalgae growth. Glob. J. Environ. Sci. Manag. 2017:3(2):217-230.

[99] Sharma R. Effects of Culture Conditions on Growth and Biochemical Profile of Chlorella Vulgaris. Journal of Plant Pathology \& Microbiology 2012:3(5). https://doi.org/10.4172/2157-7471.1000131

[100] Chen Z., Zhang X., Jiang Z., Chen X., He H., Zhang X. Light/dark cycle of microalgae cells in raceway ponds: Effects of paddlewheel rotational speeds and baffles installation. Bioresource Technology 2016:219:387-391. https://doi.org/10.1016/j.biortech.2016.07.108

[101] Zheng Y., Li T., Yu X., Bates P. D., Dong T., Chen S. High-density fed-batch culture of a thermotolerant microalga Chlorella sorokiniana for biofuel production. Applied Energy 2013:108:281-287. https://doi.org/10.1016/j.apenergy.2013.02.059

[102] Qiu R., Gao S., Lopez P. A., Ogden K. L. Effects of $\mathrm{pH}$ on cell growth, lipid production and $\mathrm{CO}_{2}$ addition of microalgae Chlorella sorokiniana. Algal Research 2017:28:192-199. https://doi.org/10.1016/j.algal.2017.11.004

[103] Ramsundar P., Guldhe A., Singh P., Bux F. Assessment of municipal wastewaters at various stages of treatment process as potential growth media for Chlorella sorokiniana under different modes of cultivation. Bioresource Technology 2017:227:82-92. https://doi.org/10.1016/j.biortech.2016.12.037

[104] Khalid A. A. H., Yaakob Z., Abdullah S. R. S., Takriff M. S. Growth improvement and metabolic profiling of native and commercial Chlorella sorokiniana strains acclimatized in recycled agricultural wastewater. Bioresource Technology 2018:247:930-939. https://doi.org/10.1016/j.biortech.2017.09.195

[105] Patel A. K., Joun J. M., Hong M. E., Sim S. J. Effect of light conditions on mixotrophic cultivation of green microalgae. Bioresource Technology 2019:282:245-253. https://doi.org/10.1016/j.biortech.2019.03.024

[106] Li Y., Zhou W., Hu B., Min M., Chen P., Ruan R. R. Effect of light intensity on algal biomass accumulation and biodiesel production for mixotrophic strains Chlorella kessleri and Chlorella protothecoide cultivated in highly concentrated municipal wastewater. Biotechnology and Bioengineering 2012:109(9):2222-2229. https://doi.org/10.1002/bit.24491

[107] Ördög V. et al. Effect of temperature and nitrogen concentration on lipid productivity and fatty acid composition in three Chlorella strains. Algal Research 2016:16:141-149. https://doi.org/10.1016/j.algal.2016.03.001

[108] Juneja A., Ceballos R. M., Murthy G. S. Effects of environmental factors and nutrient availability on the biochemical composition of algae for biofuels production: A review. Energies 2013:6(9):4607-4638 https://doi.org/10.3390/en6094607

[109] Lv J. M., Cheng L. H., Xu X. H., Zhang L., Chen H. L. Enhanced lipid production of Chlorella vulgaris by adjustment of cultivation conditions. Bioresource Technology 2010:101(17):6797-6804. https://doi.org/10.1016/j.biortech.2010.03.120

[110] Fu W., Gudmundsson O., Feist A. M., Herjolfsson G., Brynjolfsson S., Palsson B. Maximizing biomass productivity and cell density of Chlorella vulgaris by using light-emitting diode-based photobioreactor. Journal of Biotechnology 2012:161(3):242-249. https://doi.org/10.1016/j.jbiotec.2012.07.004

[111] Kobayashi N. et al. Characterization of three Chlorella sorokiniana strains in anaerobic digested effluent from cattle manure. Bioresource Technology 2013:150:377-386. https://doi.org/10.1016/j.biortech.2013.10.032

[112] Deng X. Y. et al. Glucose addition-induced changes in the growth and chemical compositions of a freshwater microalga Chlorella kessleri. Chemical Technology and Biotechnology 2019:94(4):1202-1209. https://doi.org/10.1002/jctb.5870 


\section{ANNEX}

Table A1. Key Parameters of Selected Chlorella Species

\begin{tabular}{|c|c|c|c|c|c|c|c|c|c|c|}
\hline \multirow{2}{*}{ Species } & \multicolumn{5}{|c|}{ Growth conditions } & \multirow{2}{*}{$\begin{array}{l}\text { Optimum } \\
\mathrm{CO}_{2} \\
\text { absorption }\end{array}$} & \multirow{2}{*}{$\begin{array}{l}\text { Cultivation } \\
\text { type }\end{array}$} & \multirow{2}{*}{$\begin{array}{l}\text { Application in } \\
\text { wastewater } \\
\text { treatment }\end{array}$} & \multirow{2}{*}{$\begin{array}{l}\text { High-value } \\
\text { compounds }\end{array}$} & \multirow{2}{*}{ Reference } \\
\hline & $\begin{array}{l}\text { Temp. } \\
\text { opt. }\end{array}$ & $\begin{array}{l}\text { Temp. } \\
\text { min. }\end{array}$ & $\begin{array}{l}\text { Temp. } \\
\text { max. }\end{array}$ & $\begin{array}{l}\text { pH } \\
\text { opt. }\end{array}$ & $\begin{array}{l}\text { Light, opt. } \\
\mu \mathrm{mol} / \mathrm{m}^{2} / \mathrm{s}\end{array}$ & & & & & \\
\hline C. vulgaris & $25-28$ & 5 & $28-30$ & $7-10$ & $150-750$ & $4-15 \%$ & $\begin{array}{l}\text { Phototrophic } \\
\text { Heterotrophic } \\
\text { Mixotrophic }\end{array}$ & $\begin{array}{l}\text { Urban } \\
\text { Industrial } \\
\text { Agricultural } \\
\text { Municipal }\end{array}$ & $\begin{array}{l}\text { Chlorophyll } \\
\text { Lutein, } \\
\beta-1,3 \text {-glucan }\end{array}$ & $\begin{array}{l}{[12],[14],[15],[47],} \\
{[48],[56],[68],[1],} \\
{[17],[41],[55],[57],} \\
{[61],[69]-[71]}\end{array}$ \\
\hline C. sorokiniana & $28-40$ & 20 & $38-42$ & $6-7.5$ & $100-2500$ & $5 \%$ & $\begin{array}{l}\text { Phototrophic } \\
\text { Heterotrophic } \\
\text { Mixotrophic }\end{array}$ & $\begin{array}{l}\text { Synthetic } \\
\text { Municipal } \\
\text { Agricultural }\end{array}$ & $\begin{array}{l}\text { Chlorophyll } \\
\text { Lutein }\end{array}$ & $\begin{array}{l}{[31],[60],[74],[76],} \\
{[78]-[80],[100],} \\
{[101],[77],[82],} \\
{[102]-[104]}\end{array}$ \\
\hline C. protothecoides & $25-30$ & NA & $28-32$ & NA & $30-150$ & NA & $\begin{array}{l}\text { Phototrophic } \\
\text { Heterotrophic } \\
\text { Mixotrophic }\end{array}$ & $\begin{array}{l}\text { Industrial } \\
\text { Brewery waste } \\
\text { Municipal }\end{array}$ & $\begin{array}{l}\text { Chlorophyll } \\
\text { Astaxanthin } \\
\beta \text {-carotene } \\
\text { Lutein }\end{array}$ & $\begin{array}{l}{[39],[57],[61],[85],} \\
{[86],[89],[105],[106]}\end{array}$ \\
\hline C. kessleri & $26-30$ & NA & $34-36$ & NA & $70-150$ & $18 \%$ & $\begin{array}{l}\text { Phototrophic } \\
\text { Heterotrophic } \\
\text { Mixotrophic }\end{array}$ & $\begin{array}{l}\text { Urban } \\
\text { Aquaculture }\end{array}$ & Astaxanthin & $\begin{array}{l}{[1],[20],[55],[91]-} \\
{[94]}\end{array}$ \\
\hline C. minutissima & $25-30$ & NA & 32 & 7 & 350 & NA & $\begin{array}{l}\text { Phototrophic } \\
\text { heterotrophic } \\
\text { Mixotrophic }\end{array}$ & Municipal & Lipids & $\begin{array}{l}{[17],[64],[95]-[97]} \\
{[107]}\end{array}$ \\
\hline
\end{tabular}


TABle A2. Growth Rate, Biomass Yield AND LiPID CONTENT of ChlORELLA SPeCIES

\begin{tabular}{|c|c|c|c|c|c|c|c|}
\hline \multirow[b]{2}{*}{ Species } & \multirow{2}{*}{$\begin{array}{l}\text { Max specific } \\
\text { growth rate, } \\
\mu_{\max }, d^{-1}\end{array}$} & \multirow{2}{*}{ Biomass yield, $\mathbf{g ~ L}^{-1}$} & \multicolumn{3}{|c|}{ Biomass productivity, $\mathrm{g} \mathrm{L}^{-1} \mathrm{~d}^{-1}$} & \multirow{2}{*}{$\begin{array}{l}\text { Lipid content, \%/ } \\
\text { Lipid productivity mg } \mathrm{L}^{-1} \mathrm{~d}^{-1}\end{array}$} & \multirow[b]{2}{*}{ Reference } \\
\hline & & & Phototrophic & Heterotrophic & Mixotrophic & & \\
\hline C. vulgaris & $0.293-1.457$ & $0.4-20$ & $0.02-4.64$ & 0.105 & $2-5$ & $5-58 \% / 7.5-132.4$ & $\begin{array}{l}{[1],[15],[31],[62],} \\
{[65],[66],[108]-[110]}\end{array}$ \\
\hline C. sorokiniana & $0.397-1.60$ & $25-37.6$ & $0.18-4.35$ & $0.7-12.2$ & $0.7-1.98$ & $24-31.5 \% / 49.4-94.8$ & $\begin{array}{l}{[15],[31],[38],[48],} \\
{[80],[111]}\end{array}$ \\
\hline C. kessleri & 1.27 & $4.46-13$ & NA & NA & 2.01 & $48.5-54.67 \% / 3.3-7110$ & {$[48],[91],[92],[112]$} \\
\hline C. protothecoides & $0.33-0.92$ & $12.73-51.2$ & 0.27 & $0.88-6.6$ & $1.2-1.31$ & $44.3-57.8 \% / 77.7-2120$ & $\begin{array}{l}{[15],[48],[63],[65],} \\
{[86]-[89]}\end{array}$ \\
\hline C. minutissima & 0.43 & NA & 0.143 & $0.76-1.78$ & 0.76 & $5-15 \%$ & $\begin{array}{l}{[48],[64],[65],[95],} \\
{[97]}\end{array}$ \\
\hline
\end{tabular}

NA - data not available. 